\title{
SISTEM USAHA TANI TERINTEGRASI TANAMAN-TERNAK
}

\author{
H a m k a \\ Staf Pengajar Faperta UMMU-Ternate, $\boldsymbol{e}$-mail: -
}

\begin{abstract}
ABSTRAK
Sistem usaha tani terintegrasi antara tanaman dan ternak telah lama dilakukan oleh rumah tangga petani di Indonesia, terutama di pedesaan. Umumnya rumah tangga petani menggunakan persediaan makanannya untuk mencukupi konsumsi sendiri dan selebihnya dijual. Karakteristik yang dijumpai pada petani tersebut adalah melakukan usaha tani campuran dalam upaya mendapatkan keuntungan yang maksimal dan meminimalkan risiko. Ada empat model penerapan sistem usaha tani campuran, yaitu: 1) sistem yang dipraktekkan secara alami dan turun-temurun oleh petani setempat, 2) sistem usaha tani tanpa melibatkan ternak, 3) sistem usaha tani ternak, dan 4) system usaha yang berbasis pada sumber daya lahan, tenaga kerja, dan modal. Masing-masing sistem usaha tani tersebut memiliki risiko dan ketidakpastian usaha di masa yang akan datang. Beberapa risiko mendasar pada sistem usaha tani adalah risiko produksi, risiko usaha dan finansial, serta risiko kerusakan. Dari risiko mendasar tersebut, dengan menggunakan perhitungan sistem fungsional, usaha tani terintegrasi tanaman-ternak mempunyai peluang risiko yang minimal.
\end{abstract}

\section{Kata Kunci: Usaha tani terintegrasi, sistem usaha, analisis risiko}

\section{PENDAHULUAN}

Tujuan suatu usaha tani yang dilaksanakan oleh rumah tangga petani mempunyai pengaruh yang sangat besarterhadap pengambilan keputusan dan tindakan yang akan diambil, maupun terhadap pandangan rumah tangga akan keberlangsungan dan kemampuannya dalam menerima berbagai pembaharuan, termasuk teknologi pertanian. Usaha tani yang dilakukan oleh rumah tangga petani umumnya mempunyai dua tujuan, yaitu mendapatkan keuntungan yang maksimal atau untuk sekuriti (keamanan) dengan cara meminimalkan risiko, termasuk keinginan untuk memiliki persediaan pangan yang cukup untuk konsumsi rumah tangga dan selebihnya untuk dijual.

Kenyataan di lapang menunjukkan, umumnya petani menanam dan mengusahakan berbagai jenis tanaman, ternak, dan usaha lainnya dalam suatu kesatuan usaha rumah tangga untuk mengurangi risiko serangan penyakit serta kegagalan panen. Sebagian besar lahan yang dikuasai dimanfaatkan untuk tanaman pangan dalam upaya memenuhi kebutuhan keluarga. Jenis usaha yang terpenting atau utama dan bernilai tinggi biasanya diusahakan atau ditanam di dekat tempat tinggal, sedangkan yang kurang penting atau nilainya rendah diusahakan pada lahan yang jauh dari rumah. Dengan demikian, karakteristik yang umum dijumpai adalah setiap petani selalu melakukan usaha tani campuran, terlepas dari luas pemilikan lahan, lokasi, atau kepadatan penduduk. Hal ini menunjukkan konsistensi dari kedua tujuan berusaha tani, yaitu memaksimalkan keuntungan atau meminimalkan risiko. 
Alasan lain petani melakukan usaha tani campuran adalah karena kebiasaan (tradisi), untuk memaksimalkan penerimaan dari sumber daya yang terbatas, dan meningkatkan manfaat keterkaitan antarcabang usaha, seperti tanaman dan ternak (sumber pakan), ternak dan tanah (kesuburan), serta tanaman dan tanaman (tumpang sari). Alasan tradisional tersebut sebenarnya telah tercakup dalam keinginan untuk memaksimalkan penerimaan dan meminimalkan risiko, serta keinginan mengambil manfaat dari adanya usaha tani campuran tersebut, selain memiliki dasar rasional yang jelas. Tulisan ini menyajikan cara sederhana dalam pengambilan keputusan dengan didasarkan pada beberapa faktor, seperti sumber daya yang tersedia dan tingkat penerimaan finansial dari masing-masing sumber daya tersebut, sehingga diperoleh solusi optimal yang akan memberikan keuntungan maksimal atau biaya minimal.

\section{SISTEM USAHA TERINTEGRASI}

Gambaran keterkaitan antara tanaman dan ternak dalam kerangka usaha tani tradisional adalah pemanfaatan sumber daya lahan, tenaga kerja, dan modal secara optimal untuk menghasilkan produk seperti hijauan pakan ternak, tenaga ternak, dan padang penggembalaan, serta produk akhir seperti tanaman serat, tanaman pangan, dan daging. Namun demikian, vegetasi sebagai sumber hijauan, menurut Ginting (1991), sangat berfluktuasi baik produksi maupun komposisinya. Hal ini merupakan risiko dari usaha ternak dalam suatu system tanaman-ternak, sehingga diperlukan sinkronisasi atau sinergisme antara pola pemeliharaan ternak dan dinamika vegetasi agar dicapai sasaran yang optimal. Pada sistem seperti ini, tanaman menghasilkan hijauan pakan ternak untuk menghidupi ternak yang akan menghasilkan tenaga untuk pengolahan lahan (membajak), pupuk, dan daging. Hal serupa, menurut De Boer dan Welsch (1977), juga banyak dijumpai di negaranegara berkembang dengan pola dan tujuan yang sama, yaitu meningkatkan kesejahteraan keluarga petani melalui penyebaran risiko usaha dengan menganekaragamkan komponen usaha tani.

Berdasarkan pengalaman empiris dan aplikasi model yang berlandaskan teori optimasi, integrasi ternak dalam usaha tani tanaman pangan, selain telah dilaksanakan dan dibuktikan keandalannya, memiliki beberapa prasyarat yang harus dipenuhi, antara lain: 1) kondisi dan keter ketersediaan lahan, 2) jenis komoditas, 3) tenaga kerja, 4) kebutuhan konsumsi keluarga, 5) jenis dan jumlah ternak, 6) pastura dan hijauan pakan ternak, 7) peluang transaksi komoditas, serta 8) akses kepada sumber pendanaan (modal). Kallsen (2005) menyatakan, praktek eksploitasi dengan input yang berasal dari luar dan bersifat tidak berkelanjutan masih akan berlangsung hingga 50 tahun ke depan. Usaha tani terintegrasi tanamanternak dapat merupakan solusi dari ketergantungan pada input dari luar karena sifatnya yang saling mengisi. Karena usaha tani tanaman-ternak juga merupakan bagian dari pembangunan maka pemanfaatan sumber daya alam, termasuk dalam mengurangi risiko usaha, juga harus memiliki azas keberlanjutan.

Penerapan model integrasi tanaman ternak pada suatu kawasan yang memiliki potensi pengembangan usaha tani campuran harus mempertimbangkan paling sedikit empat skenario, yaitu: 1) scenario alami yang dilakukan atau dipraktekkan oleh petani setempat, 2) skenario system usaha tani tanpa ternak, 3) skenario system usaha tani dengan ternak, dan 4) scenario yang berbasis sumber daya (lahan, tenaga kerja, modal) dan peluang pengembangan kegiatan produktif, seperti tanaman, ternak, jasa buruh, transaksi nilai tambah antarkomoditas, dan sumber-sumber pendapatan lainnya (Levine dan Soedjana 1990) .

\section{RISIKO DAN KETIDAKPASTIAN}


Masalah risiko dan ketidakpastian di bidang pertanian bukan merupakan hal baru, karena pada kenyataannya petani telah banyak mengambil keputusan yang berkaitan dengan risiko dan ketidakpastian. Yang dimaksud pengambilan keputusan dengan melibatkan faktor risiko atau ketidakpastian adalah bahwa petani tidak mengetahui apa yang akan terjadi pada masa yang akan datang. Dalam pengambilan suatu keputusan terdapat banyak kemungkinan kejadian, bergantung pada faktor-faktor lain di luar kemampuan petani untuk mengontrolnya.

Untuk mengetahui apa yang akan terjadi, biasanya digunakan berbagai informasi tentang beberapa hal yang mungkin terjadi. Tingkat pengetahuan akan informasi ini sangat bervariasi, mulai dari sangat tidak pasti sampai yang dapat diduga. Hal penting yang perlu diperhatikan dalam pengambilan keputusan yang berkaitan dengan risiko dan ketidakpastian adalah suatu keputusan yang baik belum menjamin kenyataan yang baik, karena keputusan yang baik pada dasarnya hanya merupakan sesuatu yang konsisten dengan informasi yang diperoleh serta konsisten dengan tujuannya. Dengan demikian, keputusan yang baik merupakan pilihan yang telah dipertimbangkan dengan baik yang didasarkan pada informasi yang tersedia.

Ketidakpastian diartikan sebagai suatu situasi pada suatu keadaan atau kejadian di masa mendatang yang tidak dapat diduga secara pasti. Para pengambil keputusan dapat saja memiliki pengetahuan atau tingkat kepercayaan tentang kemungkinan-kemungkinan yang akan terjadi, sehingga bila berbagai kemungkinan yang akan terjadi itu diberikan peluang yang sama, maka kita sudah menyatakan ketidakpastian itu.

Istilah risiko lebih banyak digunakan dalam konteks pengambilan keputusan, karena risiko diartikan sebagai peluang akan terjadinya suatu kejadian buruk akibat suatu tindakan. Makin tinggi tingkat ketidakpastian suatu kejadian, makin tinggi pula risiko yang disebabkan oleh pengambilan keputusan itu. Dengan demikian, identifikasi sumber risiko sangat penting dalam proses pengambilan keputusan. Nelson et al. (1978) menyatakan, faktor risiko di bidang pertanian berasal dari produksi, harga dan pasar, usaha dan finansial, teknologi, kerusakan, social dan hukum, serta manusia.

Risiko produksi terjadi karena variasi hasil akibat berbagai faktor yang sulit diduga, seperti cuaca, penyakit, hama, variasi genetik, dan waktu pelaksanaan kegiatan. Beberapa contoh adalah variasi hasil tanaman pangan, bobot sapih ternak, kualitas hasil, pertumbuhan ternak, daya tampung padang penggembalaan, tingkat kematian, dan kebutuhan tenaga kerja. Risiko harga dan pasar biasanya dikaitkan dengan keragaman dan ketidaktentuan harga yang diterima petani dan yang harus dibayarkan untuk input produksi. Jenis keragaman harga yang dapat diduga antara lain adalah trend harga, siklus harga, dan variasi harga berdasarkan musim. Tingkat harga dapat berpengaruh pada harapan pedagang, spekulasi, program pemerintah, dan permintaan konsumen.

Risiko usaha dan finansial berkaitan dengan pembiayaan dari usaha yang dijalankan, modal yang dipengaruhinya serta kewajiban kredit. Risiko usaha menjadi makin tinggi bila modal investasi atau pinjaman modal usaha menjadi lebih banyak. Pengeluaran untuk biaya tunai yang makin tinggi akan meningkatkan risiko tidak tersedianya uang tunai untuk membayar hutang dan kewajiban financial lainnya.

Adopsi cara baru, yang dikaitkan dengan risiko teknologi, berkaitan dengan perubahan yang tejadi setelah pengambilan keputusan dan akibat cepatnya kemajuan teknologi. Adopsi teknologi baru yang terlalu cepat atau terlalu lambat merupakan risiko yang harus dihadapi. Pembelian suatu alat baru, misalnya, harus memperhitungkan kemajuan teknologi 
yang akan mempengaruhi tingkat efisiensinya dalam waktu yang singkat.

Risiko kerusakan merupakan sumber risiko tradisional, misalnya kehilangan harta karena kebakaran, angin, banjir atau pencurian. Kehilangan yang disebabkan oleh tingginya inflasi dirasakan makin meningkat. Risiko sosial dan hukum berkaitan dengan peraturan pemerintah dan keputusan lainnya, seperti peraturan baru mengenai penggunaan input produksi, pembatasan subsidi, dan perencanaan lokasi baru untuk daerah pertanian.

Risiko faktor manusia berkaitan dengan perilaku, kesehatan, dan sifat-sifat seseorang yang tidak terduga sehingga dapat mengakibatkan risiko dalam usaha tani. Kehilangan pekerja utama pada saat keahliannya diperlukan dapat mempengaruhi tingkat produksi yang akan dicapai. Ketidakjujuran dan tidak dapat dipercayanya seseorang dapat pula mengakibatkan pelaksanaan usaha tani menjadi kurang efisien yang akhirnya menurunkan produksi.

Risiko dan ketidakpastian menjadi masalah karena dapat menyebabkan sistem ekonomi menjadi kurang efisien. Sebagai contoh, karena meningkatnya ketidakpastian, petani tidak memberikan pupuk pada takaran yang dianjurkan, sehingga hasil yang dicapai rendah. Karena ketidakpastian, petani tidak mau meningkatkan skala usahanya untuk efisiensi tenaga kerja dan peralatan. Ketidakpastian juga berimplikasi pada tata laksana bagi petani. Oleh karena itu diperlukan beberapa pendekatan dalam pengambilan keputusan yang melibatkan risiko, yaitu: 1) melakukan analisis terhadap keputusan yang akan diambil dari berbagai pilihan yang tersedia, kemungkinan kejadiannya, serta manfaatnya bila keputusan itu harus ditentukan, 2) memperkirakan peluang yang akan terjadi dengan tingkat manfaat yang akan diperoleh, dan 3) mempertimbangkan perilaku, kemampuan, dan tujuan pengambil keputusan berkaitan dengan tingkat risiko yang harus dihadapi karena keputusan yang telah diambil.

\section{SKALA USAHA TANI}

Skala usaha dalam suatu sistem usaha tani dapat diukur dengan berbagai cara, antara lain dari investasi, biaya tetap, biaya variabel, total nilai penjualan, luas areal tanam, dan jumlah satuan ternak. Perhitungan biaya setiap luasan areal tanam atau satuan ternak dapat dilakukan untuk melihat perbedaan efisiensi di antara petani yang mengusahakan komoditas serupa.

Biaya investasi adalah biaya yang diperlukan petani pada saat memulai usahanya dan yang akan dikeluarkan kembali pada saat atau usia ekonomis investasi tersebut telah habis. Termasuk dalam biaya investasi adalah tanah, bangunan, mesin, bibit ternak, dan peralatan tidak habis pakai. Biaya tetap adalah biaya produksi yang dikeluarkan oleh petani atau peternak dan tidak dipengaruhi oleh besar kecilnya produksi dalam suatu siklus produksi, misalnya biaya kandang, peralatan, perbaikan, depresiasi, dan upah manajer. Biaya operasional atau biaya variabel adalah biaya yang berubah-ubah sesuai dengan perubahan produksi, seperti biaya pakan konsentrat, hijauan, mineral, obat-obatan, serta tenaga pemelihara atau buruh. Total nilai penjualan biasanya dihitung setiap tahun dan untuk menentukan besarnya pajak yang harus dibayar. Cara seperti ini dilakukan di negara yang sudah maju dan digunakan juga untuk mengelompokkan skala usaha kecil, menengah, dan besar. Skala usaha juga dapat diukur dengan melihat luas areal yang diusahakan oleh petani atau satuan ternak yang dimiliki peternak. Dalam sistem usaha yang terintegrasi, kombinasi komponen usaha tani tersebut menentukan besarnya usaha.

Pendekatan titik impas dapat digunakan untuk menentukan skala usaha. Secara umum, karena adanya respons petani terhadap tingkat risiko usaha yang dihadapi, maka skala usaha dapat dilihat 
dari keuntungan yang diperoleh dengan cara menjabarkan berbagai prasyarat teknis maupun ekonomi yang memberikan kontribusi terhadap keuntungan tersebut.

Untuk itu, skala usaha dapat dilihat dari pendekatan titik impas. Fungsi keuntungan (TT) dapat memperlihatkan hubungan tersebut dan masing-masing variabelnya dapat dijabarkan lebih jauh untuk melihat prasyarat teknis maupun ekonomi sebagai berikut:

$$
\begin{aligned}
\mathrm{TT} & =\mathrm{TR}-\mathrm{TC} \ldots \ldots \ldots \\
& =\mathrm{TR}-(\mathrm{VC}+\mathrm{F}) \\
& =\text { Py. } \mathrm{Y}-\mathrm{Px} . \mathrm{X}-\mathrm{F}
\end{aligned}
$$

Py = harga produk yang diproduksi

$\mathrm{Y} \quad=$ fungsi produksi, $\mathrm{f}(\mathrm{Y})$

$\mathrm{Px} \quad=$ harga masing-masing input (Xi)

$\mathrm{X} \quad$ = input yang digunakan

$\mathrm{F} \quad=$ biaya tetap

Py.Y = total penerimaan (TR)

Px. $X+F=$ total biaya $(T C)$

Dengan menggunakan pendekatan fungsi keuntungan, skala usaha dapat dilihat dengan cara menentukan titik impas produksi maupun harga. Titik impas ditentukan pada kondisi di mana $\mathrm{TT}=0$, atau pada saat TR $=$ TC. Variasi perubahan harga input maupun harga produk akan menunjukkan berapa besar produksi harus dilakukan untuk mencapai keuntungan. Analisis ini dapat dilakukan dengan menggunakan grafik maupun perhitungan langsung dengan formula, melalui penentuan jumlah unit yang diproduksi (Y), harga jual per unit (Py), serta biaya tetap (F) dan biaya tidak tetap (VC).

Titik impas dapat juga dihitung dengan menggunakan: 1) formula pendapatan, $\mathrm{TI}=\mathrm{F} /(\mathrm{VC} / \mathrm{P})$, dan 2) formula langsung, $\mathrm{TI}=\mathrm{F} /(\mathrm{P}-\mathrm{VC})$. Misalnya, suatu usaha tani memerlukan biaya tetap untuk memproduksi suatu komoditas sebesar Rp500 dan setiap unit produk memerlukan biaya variabel $\mathrm{Rp} 1$, serta harga jual produk tersebut di pasaran Rp2/unit. Titik impas akan diperoleh pada kondisi TR $=$ TC, yaitu Py.Y $=$ Px.X $+F$, sehingga $2 \mathrm{Y}=1 \mathrm{Y}+500$ atau $\mathrm{Y}=500$ unit. Dengan menggunakan formula pendapatan, yaitu $\mathrm{TI}=\mathrm{F} /(\mathrm{VC} / \mathrm{P})$, di mana $\mathrm{TI}=500 /(1 / 2)=1.000$, titik impas diperoleh pada tingkat pendapatan Rp1.000 atau pada saat produksi (Y) mencapai $1.000 / 2=500$ unit. Jika menggunakan formula langsung, $\mathrm{TI}=\mathrm{F} /(\mathrm{P}-\mathrm{VC})$ diperoleh tingkat produksi (Y) sebesar $500 /(2-1)=500$ unit.

Variasi tingkat keuntungan, volume produksi, dan persentase perubahannya dapat dilakukan melalui analisis kepekaan (sensitivity analyses) pada berbagai tingkat yang dikehendaki, sehingga dapat diketahui skala produksi yang dikehendaki serta berbagai konsekuensinya. Usaha tani terpadu tanaman dan ternak akan berhasil bila mempertimbangkan aspek keberlanjutan, ramah lingkungan, serta secara sosial dan politis dapat diterima masyarakat. Oleh karena itu, penerapan sistem ini akan bervariasi pada setiap wilayah, bergantung pada kondisi geografis, ekologis, dan sosial ekonomi masyarakat setempat dalam hal jenis ternak, sistem budi daya, perkandangan, maupun komponen teknologi lainnya (Diwyanto et al. 2002).

\section{DISTRIBUSI PELUANG}

Peluang adalah suatu angka yang menunjukkan kemungkinan atau peluang bahwa suatu kejadian akan terjadi. Suatu kejadian merupakan peristiwa yang dapat terjadi di masa mendatang di luar pengetahuan kita. Angka yang menunjukkan peluang bervariasi dari 0 sampai 1. Angka 0 berarti tidak ada peluang sama sekali suatu kejadian akan terjadi, sedangkan angka 1 berarti sangat mungkin untuk terjadi. Selain itu, penjumlahan dari angka-angka peluang tersebut menunjukkan suatu situasi dan berjumlah 1 .

Ada tiga jenis peluang berdasarkan cara pengukurannya atau cara menurunkannya, yaitu secara empiris, deduktif, dan subjektif. Peluang yang diperoleh secara empiris didasarkan pada frekuensi observasi empiris. 
Pengelompokan observasi dapat dilakukan melalui pembentukan interval untuk digunakan dalam pendugaan peluang atau frekuensi dari beberapa kejadian. Peluang yang diperoleh secara empiris dari data historis sangat berguna dalam manajemen, tetapi kurang berguna untuk hal lain. Peluang yang diperoleh secara deduktif dilakukan dengan cara deduksi dengan mengasumsikan peluang kejadian adalah acak. Namun demikian, umumnya fenomena yang dipertimbangkan tidak selalu mengikuti atau mengacu kepada deduksi logis.

Peluang yang diperoleh secara subjektif mengukur keyakinan seorang pengambil keputusan tentang kemungkinan terjadinya suatu kejadian di masa mendatang. Dalam pengukuran peluang seperti ini, diasumsikan bahwa pengambil keputusan menguji pengalamannya sendiri melalui data yang tersedia untuk merangkum seluruh kejadian. Peluang yang diperoleh secara subjektif dapat dilakukan melalui tiga cara yaitu: 1) menggunakan pendekatan distribusi kumulatif, 2) menggunakan conviction weights atau pendugaan tertimbang, dan 3) estimasi secara langsung. Ketiga cara tersebut harus dihitung dari distribusi peluang yang sama. Cara lain untuk mengestimasi distribusi peluang subjektif adalah melalui distribusi trianguler, yang memiliki keleluasaan dalam bentuk distribusi.

\subsection{Metode Simplex}

Pendekatan simplex juga dapat digunakan untuk menentukan skala usaha suatu sistem usaha yang terdiri atas beberapa komponen, seperti usaha tani campuran. Untuk menerapkan pendekatan fungsi keuntungan dalam suatu sistem usaha tani ternak yang terintegrasi atau usaha tani campuran, metode simplex atau metode linear programming dapat digunakan untuk melihat berbagai pilihan yang akan menghasilkan skala usaha tertentu (optimum solution) sebagai respons terhadap ketersediaan sumber daya, harga input, dan gross-margin dari masingmasing komponen usaha. Algo-ritme seperti yang digunakan pada metode ini juga digunakan dalam proses kalkulasi pada metode linear programming yang menggunakan koefisien teknis yang jauh lebih besar dan kompleks. Namun, untuk pengenalan metode optimisasi yang sederhana, metode simplex dapat dipertimbangkan (Lipschutz 1966).

Contoh untuk pendekatan simplex adalah seorang petani yang mengusahakan tanaman pangan sambil memelihara ternak. Kedua jenis usaha ini masing-masing menggunakan lahan (L), tenaga kerja (K), dan modal (M). Petani tersebut mempunyai 16 ha lahan, 11 HOK tenaga kerja keluarga, dan Rp15.000 modal kerja. Untuk satu unit usaha tanaman pangan diperlukan 2 ha lahan, 1 HOK tenaga kerja, dan Rp1.000 modal kerja, sedangkan untuk pemeliharaan ternak diperlukan 1 ha lahan untuk hijauan pakan, 2 HOK tenaga kerja untuk pemeliharaan ternak, dan Rp3.000 modal kerja. Apabila keuntungan setiap unit usaha tanaman sebesar Rp30.000 dan untuk setiap unit usaha ternak Rp50.000, maka berapa unit usaha tani tanaman pangan dan berapa unit usaha ternak harus dijalankan untuk memperoleh keuntungan yang maksimal? Narasi tentang system usaha tani campuran tersebut dapat dijabarkan ke dalam Matriks 1-5.

Metode simplex dimulai dengan memilih pivot entry dengan cara: 1) memilih salah satu kolom yang memiliki indicator atau tanda negatif terbesar sebagai pivotal column, 2) membagi setiap entry positif pada kolom ini kepada entry yang bersesuaian pada kolom terakhir, dan 3) memilih angka hasil pembagian yang terkecil sebagai pivot. Selanjutnya matriks awal (Matriks 1) diubah ke dalam format simplex yang mempunyai bentuk sebagai berikut:

\begin{tabular}{ccc}
\hline$A$ & $I$ & $b$ \\
\hline$-C$ & 0 & 0 \\
\hline
\end{tabular}

Dimana A adalah matriks koefisien teknis, I adalah matriks identitas $(0 \square 1)$, b 
adalah vektor ketersediaan sumber daya, dan c adalah vektor keuntungan.

\begin{tabular}{lccc} 
Matrik 1 & & & \\
\hline $\begin{array}{l}\text { Sumber } \\
\text { lahan }\end{array}$ & $\begin{array}{l}\text { Usahatani } \\
\text { pangan }\end{array}$ & $\begin{array}{c}\text { Usaha } \\
\text { ternak }\end{array}$ & $\begin{array}{c}\text { Ketersediaan } \\
\text { Sumber daya }\end{array}$ \\
\hline Lahan & 2 & 1 & 16 \\
Tenaga & 1 & 2 & 11 \\
kerja & 1 & 3 & 15 \\
Modal & & & \\
\hline & & & \\
\hline
\end{tabular}

Matrik 2

\begin{tabular}{cccccc}
\multicolumn{2}{l}{$\mathrm{P} 1$} & $\mathrm{P} 2$ & & & \\
\hline 2 & 1 & 1 & 0 & 0 & 16 \\
\hline 1 & 2 & 0 & 1 & 0 & 11 \\
\hline 1 & 3 & 0 & 0 & 1 & 15 \\
\hline-30 & -50 & 0 & 0 & 0 & 0 \\
\hline
\end{tabular}

Matrik 3

\begin{tabular}{cccccc}
\multicolumn{1}{l}{$\mathrm{P} 1$} & $\mathrm{P} 2$ & & & & \\
\hline $5 / 3$ & 0 & 1 & 0 & $-1 / 3$ & 11 \\
\hline $1 / 3$ & 0 & 0 & 1 & $-2 / 3$ & 1 \\
\hline $1 / 3$ & 1 & 0 & 0 & $1 / 3$ & 5 \\
\hline$-40 / 3$ & 0 & 0 & 0 & $50 / 3$ & 250 \\
\hline
\end{tabular}

Matrik 4

\begin{tabular}{cccccc} 
P1 & P2 & & & & \\
\hline 0 & 0 & 1 & -5 & 3 & 6 \\
\hline 1 & 0 & 0 & 3 & -2 & 3 \\
\hline 0 & 1 & 0 & -1 & 1 & 4 \\
\hline 0 & 0 & 0 & 40 & -10 & 290 \\
\hline
\end{tabular}

Matrik 5

\begin{tabular}{rrrrrc}
\multicolumn{1}{l}{$\mathrm{P} 1$} & $\mathrm{P} 2$ & & & & \\
\hline 0 & 0 & $1 / 3$ & $-5 / 3$ & 1 & 2 \\
\hline 1 & 0 & $2 / 3$ & $-1 / 3$ & 0 & 7 \\
\hline 0 & 1 & $-1 / 3$ & $2 / 3$ & 0 & 2 \\
\hline 0 & 0 & $10 / 3$ & $70 / 3$ & 0 & 310 \\
\hline
\end{tabular}

Pada Matriks 5 ditunjukkan bahwa keuntungan maksimal petani dari sistem usaha tani dapat mencapai Rp310.000 dengan cara melakukan usaha tani tanaman pangan seluas $10 / 3$ atau 3,30 unit usaha dan 70/3 atau 23,30 unit usaha ternak. Nilai akhir dari proses simplex ini dimulai dari 0 , 250, 290 dan akhirnya 310, seperti yang terlihat pada Matriks $2 \square 5$.

Keseluruhan proses dimulai dari 1) pembentukan tabel awal, 2) menentukan pivot entry yang ditandai oleh cetak tebal pada setiap tabel, 3) menghitung nilai-nilai baru pada tabel atau matriks berikutnya berdasarkan pivot entry, dan 4) mengulangi seluruh proses (tahap 2 dan 3) sampai ditemukan tabel akhir. Contoh analisis pendekatan simplex dengan melibatkan jumlah kegiatan yang lebih banyak dalam satu usaha tani campuran ditunjukkan oleh Young dan Rickards (1978).

Solusi optimal dari pendekatan ini telah memberikan komposisi usaha tani yang optimal dalam upaya memberikan keuntungan yang maksimal kepada petani.

\section{KESIMPULAN}

Tujuan suatu rumah tangga petani dalam menjalankan usaha tani adalah untuk memaksimalkan keuntungan atau untuk keamanan dengan cara meminimalkan risiko, termasuk keinginan untuk memiliki persediaan pangan yang cukup untuk konsumsi rumah tangga dan selebihnya untuk dijual. Apabila pilihan terakhir ini dijumpai pada rumah tangga petani, maka karakteristik yang umum dijumpai adalah setiap petani selalu melakukan usaha tani campuran, terlepas dari luas pemilikan lahan, lokasi, atau kepadatan penduduk.

Hal ini menunjukkan konsistensi dari kedua tujuan berusaha tani, yaitu memaksimalkan keuntungan atau meminimalkan risiko. Alasan tersebut sebenarnya telah tercakup dalam keinginan untuk memaksimalkan penerimaan dan meminimalkan risiko, serta keinginan mengambil manfaat dari usaha tani campuran yang memiliki dasar rasional yang jelas.

Istilah risiko lebih banyak digunakan dalam konteks pengambilan keputusan, karena risiko diartikan sebagai peluang akan terjadinya suatu kejadian buruk yang disebabkan oleh suatu tindakan. Makin tinggi tingkat ketidakpastian suatu kejadian, makin tinggi risiko akibat pengambilan keputusan tersebut. Dengan demikian, identifikasi sumber risiko sangat penting dalam proses pengambilan keputusan. 


\section{DAFTAR PUSTAKA}

Amir, P. and H.C. Knipscheer. 1989. Conducting on farm animal research: Procedures and economic analysis. Winrock International, Morrilton, Arkansas.

De Boer, A.J. and D.E. Welsch. 1977. Constraints on cattle and buffalo production in a Northern Thai Village. In R.D. Stevens (Ed). Tradition and Dynamics in SmallFarm Agriculture, Economic Studies in Asia, Africa and Latin America. The Iowa State University Press, Ames.

Diwyanto, K., B.R. Prawiradiputra, dan D. Lubis. 2002. Integrasi tanaman-ternak dalam pengembangan agribisnis yang berdaya saing, berkelanjutan dan berkerakyatan. Wartazoa, Buletin Ilmu Peternakan Indonesia 12(1): 1-8.

Ginting, S.P. 1991. Keterpaduan ternak ruminansia dengan perkebunan: 2. Pola pemeliharaan dan produksi ternak. Jurnal Penelitian dan Pengembangan Pertanian X(1): 9-12.

Prawirosentono Suyadi. 2005. Riset Operasi dan Ekonofisika.PT. Bumi Aksara, Jakarta 